\title{
Conceptualizing Cuvée Organizations: Characteristics Leading towards Sustainable Decision-Making Practices
}

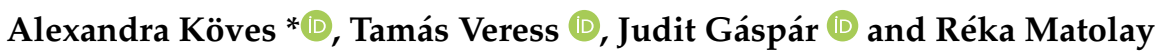 \\ Department of Decision Sciences, Institute for Business Economics, Corvinus University of Budapest, \\ 1093 Budapest, Hungary; tamas.veress@uni-corvinus.hu (T.V.); judit.gaspar@uni-corvinus.hu (J.G.); \\ reka.matolay@uni-corvinus.hu (R.M.) \\ * Correspondence: alexandra.koves@uni-corvinus.hu
}

check for updates

Citation: Köves, A.; Veress, T.;

Gáspár, J.; Matolay, R.

Conceptualizing Cuvée

Organizations: Characteristics

Leading towards Sustainable

Decision-Making Practices.

Sustainability 2021, 13, 13672. https:/ /

doi.org/10.3390/su132413672

Academic Editor: Carlos

Rodríguez Monroy

Received: 30 October 2021

Accepted: 8 December 2021

Published: 10 December 2021

Publisher's Note: MDPI stays neutral with regard to jurisdictional claims in published maps and institutional affiliations.

Copyright: (c) 2021 by the authors. Licensee MDPI, Basel, Switzerland. This article is an open access article distributed under the terms and conditions of the Creative Commons Attribution (CC BY) license (https:/ / creativecommons.org/licenses/by/ $4.0 /)$.
Abstract: This paper discusses the role and responsibility of business organizations in a sustainability transition with a thought-provoking hypothetical construct, the cuvee organization. The aim of the paper is to introduce and conceptualize this normative concept on what sustainable and responsible business would look like in an ideal world-more specifically, which meta features should characterize a business organization that is designed for sustainability? It also tests the concept's applicability to a micro-process, an everyday challenge any organization aiming for sustainability would face, namely discounting. The concept of the cuvée organization emerged from participatory backcasting, a normative scenario-building exercise conducted with a sustainability expert panel. In this co-creative process, the panel capitalized on the metaphor of cuvée wine and winemaking, which provided the cognitive means to chart the unknown. The emerged concept of the cuvée organization stands for a business archetype which is designed to serve a prosocial cause, subordinating activities and structural features accordingly. When applying this construct to discounting, our approach lies with ecological rationality in behavioral decision making as well as the practice-based approach of corporate strategy research. In this theoretically rigorous effort, we aim to show which metacharacteristics could support an organizational structure leading to better decision making, aiming to avoid various forms of temporal and spatial discounting. The originality of the research is filling the normative vision with details through the conceptualization of the cuvée organization. On the level of methodologies, our research contributes to understanding the novelty and applicability of backcasting processes and provides an astounding example for the use of metaphors in future studies.

Keywords: sustainable business; discounting; decision making; cuvée organization; backcasting; metaphors

\section{Introduction}

As ecological demises caused or aggravated by current social metabolisms are no longer questioned by the majority in our societies, the quest to find a way out of our unsustainable economic and social practices has intensified [1]. The demand to plan and initiate sustainability transformations almost always entails the claim to seriously alter business practices and overthrow the reigning atomistic and utilitarian approaches that allow businesses to thrive in an environment where their own interest earns primacy over collective ecological and social concerns [2]. There is an intensified ongoing scientific discourse on sustainable business models (SBM) [3,4], more sustainable business models (MSBM) [5], sustainable business model innovation (SBMI) [6,7], organizational sustainability [8], social business [9], and degrowth business [2]. All these concepts appear to find adequate answers to transforming business practices for people and the planet. Most of them are descriptive and base their findings on looking at existing practices [3,7-10], while other approaches are more prescriptive in their quest to suggest organizational processes, characteristics, practices to achieve sustainability [2,5]. The concept we introduce 
in this paper, cuvée organizations, is neither descriptive because it does not claim that such organizations exist nor prescriptive because it does not intend to impose or enforce models or rules to existing businesses. By the nature of the methodology behind the birth of the concept, namely backcasting, it is normative: it describes a business typology that a group of people deem desirable with organizational characteristics that they wish to see in a future where sustainability is the norm. Hence, by describing these normative characteristics, this paper neither tries to introduce a brand-new model of business based on existing trends with an analysis on its feasibility, nor is it a response to any existing gaps in the literature on sustainable business models. By introducing a normative concept that emerged from qualitative research, it wishes to add to our understanding on how meta-characteristics of an economic organization result in a more sustainable modus operandi. Moreover, we believe that the metaphor of winemaking contributes significantly to understanding the fine details of a transformation that may or may not yet be taking place in the business sector.

In 2016, an expert panel was set up to take part in qualitative research that explored the question of what sustainable and responsible business would look like in an ideal world and find potential intervention steps that nudge current economic actors towards that desired state. The methodological framework used was participatory backcasting, a normative scenario-building exercise that starts by envisioning the future and working our way back from that future to the present identifying necessary steps along the way [11,12]. Our choice fell on the use of backcasting as the non-existence of a truly sustainable and responsible business sphere in the real-world prompts the application of transition management tools that enable us to understand where we might want to transit to and what interventions we need now to have better chances of ending up there. During the twoday research workshop, expert participants-with knowledge on sustainability issues in current business-invented the term "cuvée organization" to describe an entity in the desired future that most resembles their ideals, and they used this metaphor all along to describe how these organizations operate and come about. By using the term "cuvée" they intended to underline how just blending for-profit and nonprofit organizational characteristics (the two different wines in their metaphor) only results in new qualities if it is done with adequate care, timing and relying on the best properties of both wines. In their understanding, cuvée qualities in an economic organization only happen if profit-seeking is being replaced by dedication to a social or ecological cause; competition by coopetition; atomistic and self-interested systems views by network-based embeddedness. After the backcasting research, as researchers we attempted to deepen our understanding of this newly developed concept by initiating interdisciplinary cooperation with artists and even viticulture experts.

Hence, cuvée organization is a concept created by the expert participants. It is an emergent concept that relies on the practical experiences of the participants in their present realities; their underlying understandings of descriptive and prescriptive business models; and their own personal desires and norms that influence normative images of the future. However, due to the limited timeframe of the backcasting workshop and the panel's focus on building a vision and a roadmap, an academically rigorous conceptualization of the cuvée organization was not developed. The aim of the current paper is to conceptualize the concept of the cuvée organization in theoretically rigorous quality. This conceptualization is based on our understanding of this hypothetic organizational type as one that is designed to serve as a vehicle for collective action creating value in an ethical and socioecologically sustainable manner. The conceptualization is therefore based on a normative concept that emerged in qualitative research inspired by the everyday practices and desires of expert participants coupled with existing theories applied by the researchers. Because our intention is not to create a new typology, using scientific literature serves as a tool to explain the characteristics of this normative concept and not to find its deserved place among existing models. The originality of the research is hence filling the normative vision of expert participants with details through the conceptualization of the cuvée organization. 
We argue that our reasoning and our approach in this process is abductive because we are creating scientific knowledge of social life "by drawing on the concepts and meanings used by social actors, and the activities in which they engage" [13] (p. 176). Therefore, our reasoning is not deductive because we are not using general statements or any rules to apply them to a certain case, nor are we inductive in our approach because we are not starting from theory or an existing gap in the literature and investigating the given phenomena to agree with the concepts of the theory at hand [13]. In our backcasting research process, participants shared their everyday understanding and meaning making on the business organization of the future that then led through their deliberative, participatory interaction from which the concept of the cuvée organization emerged as a description of a possible yet currently only desired future. Abduction was applied here to find explanation and to elaborate possible insights of this commonly created concept.

Therefore, in our current paper, we use the metaphor of cuvée wine to describe a normative concept of an entity with specific organizational characteristics. Regarding the use of metaphors in economics, Hardt [14] argues that they provide cognitive means to chart the unknown, and metaphors can serve as means to find yet unchartered perspectives. To be more precise, we are constructing an expanded metaphor, that is an analogy, which is a "sustained and systematically elaborated metaphor" [15] (p. 35). Accordingly, in our paper we are constructing the cuvée organization through systematically describing its key characteristics using cuvée wine as a source for inspiration and a cognitive foundation. However, it is important that we try to introduce this new "label" to energize the discussions, debates, and actions for a sustainable and responsible future and not to come up with a hypothetical organizational type.

In the new millennium, the "practice turn" has gained ground also in corporate strategy research [16]. The practice-based approach aims to come closer to the local logic of practice [17]. According to this interpretation, reality cannot be described by complex correlations but puts the focus on everyday activities, the inner logic of actions, their microprocesses, and events [18,19]. The practice-based approach to corporate strategy attempts to create a dialogue between content and process research, assuming that content is an integral component of the strategy-making process, and its ultimate goal is to dive deeper in the strategy-making processes. Our approach in this paper is also practice-oriented, with the novelty of placing reality into the imagined future, by defining the desired practices of the so-called cuvée organization. This practice-orientation is the reason why we are not just focusing on the general meta-level description of the cuvée organization but also zoom into one single, narrow perspective of fighting discounting as an example of a "micro process". Linking the overall idea of the cuvée organization to discounting, a specific subtheme of behavioral decision making, provides on the one hand substance to the concepts used in the backcasting research, and on the other, it tests its applicability to an everyday challenge any organization aiming for sustainability would face. Discounting is chosen for its significant relevance to sustainability. Through this endeavor we hope to showcase how the general organizational characteristics of the cuvée organization can lead to better decision making in terms of ecological and social responsibility. We thereby aim to contribute to ongoing scientific discourses both on transforming businesses into a more sustainable modus operandi and on more adequate decision making for the sake of sustainability.

The paper consists of seven sections. After the introduction, the methodological background of our research is presented. Section 3 describes the meta-level characteristics of the cuvée organization. Section 4 uses the phenomena of discounting to showcase how the cuvée organization is better suited to tackle discounting issues in its decisionmaking processes in order to become more sustainable. Section 5 turns back to the original metaphor of cuvée winemaking providing some insights and raising questions about the development of this hypothetical organizational model. The last two sections provide our discussion and our conclusions. 


\section{Methodology}

The research project was launched at the end of 2015 in cooperation of three organizations: the Corvinus University of Budapest, the Business Council for Sustainable Development in Hungary (BCSDH) and the Civil Auction Foundation (CAF). All three organizations were committed to finding the paths for a peaceful transition to a more sustainable and responsible economic and social modus operandi. The research sought the answers to the question of what the business of the future could look like. Because it is crucial for sustainability issues to break away from the traditional social, environmental, and economic fundamentals that determine our current ways of thinking, we need innovative methods that can help in transcending them. For this reason, the method of backcasting was chosen.

Backcasting is one of the future research methods of normative scenario building that explores the possible future perspectives of social organizations (be it on organizational, different geographical or on societal levels) $[11,12,20]$. Instead of using the current situation as a starting point for forecasting the future, the novelty of the method is to begin by creating an ideal normative vision of the future, linking that image backwards in time with the present, and identifying the steps that can lead to such an imaginary future. The English name of the technique also refers to this when replacing the prefix 'fore/casting' with the prefix 'back/casting'.

The method assumes that our current ways of thinking and its lock-in effects can adversely affect the actions we are willing to take now. For this reason, the visions of actors also have a major impact on the actions. Hence, it differs significantly from the basic principles of forecasting. Another important difference is the perception of the actors themselves. While forecasting assumes that actors are simply drifting with external trends and events, backcasting is based on the presumption that actors can move towards certain futures, and in the feedback processes there is uninterrupted interaction between action and vision. Therefore, both actions and future directions can be influenced.

Backcasting is especially effective in an environment where the future is uncertain, the heterogeneous systems involved are complex, and the outputs predicted by current trends are unacceptable. Thus, backcasting is most needed when system-level innovations are essential to break current trends. Therefore, the multidisciplinary, multidimensional, and multilevel approach of backcasting generally fits well with sustainability issues. All in all, this normative approach can generate broad visions of alternatives that go beyond mainstream frameworks and identify innovative interventions that may not yet be present or sufficiently prominent in our thinking. The responsibility of economic actors in terms of environmental and social sustainability is a highly complex problem to which the chosen methodology fits well. In our abductive [12] approach, we wanted to know how an expert panel can envision the future of business and plan its way back from that future to the present identifying potential intervention steps. The advantage of using this qualitative, participatory methodology is that it can uncover the cognitive framings of these experts on crucial issues without the need to follow only currently available paradigms and realities and enables them to leave existing path dependencies and lock-in effects behind when unfolding their common understanding on how they wished things would work in the future. This opens up new avenues for thoughts, creating a space both for creativity and value choices uncommon or deemed unrealistic in the present.

Table 1 provides an overview of our qualitative research process. In the preparatory phase, the three organizations together determined the central topic of the backcasting research. While at first sight this may not be a challenging task, even just giving a title to the project proved difficult. The title of the backcasting project in direct translation from Hungarian was 'What will the future company look like?-Sustainable and Responsible Economic Actors in 2050'. It was precisely because of the novel approaches inherent in the method that it was difficult to give a title that did not pre-empt thinking. (In Hungarian "sustainable business" would have narrowed the scope down too much.) While the method itself helped determine the time span, it is, for example, much more difficult to formulate 
what the most important economic actors in the future will be called. While we wrote companies in the title, we left open the possibility that participants would determine for themselves what types of actors they would imagine in an ideal future.

Table 1. Overview of the research process.

\begin{tabular}{|c|c|c|c|c|}
\hline & Research Phase & Task & Participants & Outputs \\
\hline \multirow{3}{*}{ Backcasting } & Preparatory phase & $\begin{array}{l}\text { Determining the topic } \\
\text { Selecting participants }\end{array}$ & $\begin{array}{c}\text { Researchers and members } \\
\text { of cooperating } \\
\text { organizations }\end{array}$ & $\begin{array}{l}\text { Briefing sent to } \\
\text { participants }\end{array}$ \\
\hline & $\begin{array}{l}\text { Backcasting workshop } \\
\text { (two-days) }\end{array}$ & $\begin{array}{l}\text { Envisioning the future } \\
\text { and designing the } \\
\text { backcasted intervention } \\
\text { roadmap }\end{array}$ & $\begin{array}{l}\text { Backcasting participants } \\
\text { (12 experts from business, } \\
\text { civil society, and academic } \\
\text { sectors) }\end{array}$ & $\begin{array}{c}\text { Backcasting vision } \\
\text { Backcasting steps } \\
\text { Backcasting roadmaps }\end{array}$ \\
\hline & $\begin{array}{c}\text { Follow-up of } \\
\text { backcasting workshop }\end{array}$ & $\begin{array}{l}\text { Systematization of } \\
\text { roadmap }\end{array}$ & $\begin{array}{c}\text { Researchers and members } \\
\text { of cooperating } \\
\text { organizations }\end{array}$ & $\begin{array}{c}\text { Systems map [21] } \\
\text { Research report [22] }\end{array}$ \\
\hline Art \& Science & $\begin{array}{l}\text { Deepening our } \\
\text { understanding of the } \\
\text { vision }\end{array}$ & $\begin{array}{l}\text { Using artistic tools to } \\
\text { enhance } \\
\text { comprehension of the } \\
\text { vision [23] }\end{array}$ & Researchers & $\begin{array}{c}\text { Theatrical Action Game } \\
\text { (Future \& Co.) }[23,24]\end{array}$ \\
\hline Metaphor & $\begin{array}{l}\text { Unfolding the } \\
\text { metaphor }\end{array}$ & $\begin{array}{c}\text { Expanding the } \\
\text { conceptualization of } \\
\text { the cuvée organization } \\
\text { through understanding } \\
\text { cuvée winemaking }\end{array}$ & $\begin{array}{l}\text { Researchers; viticulture } \\
\text { expert; some of the expert } \\
\text { participants from the } \\
\text { backcasting workshop; } \\
\text { other faculty members }\end{array}$ & $\begin{array}{l}\text { Mind-map on the } \\
\text { relevance of the } \\
\text { winemaking metaphor }\end{array}$ \\
\hline
\end{tabular}

In the preparatory phase, participants also had to be selected. The researchers opted for an expert panel involving twelve people working already with sustainability topics in their own environments. The experts covered business, civil society, and academic sectors, many of the participants managing companies that already aim at reaching sustainability in their operations. Due to the expected limitations in the availability of expert participants, certain dimensions had been predetermined by the researchers to facilitate the initial focus of the upcoming discussions. These dimensions were determined by the spatial and temporal relationship between actions and consequences so that the envisioning began looking at the responsibilities of sustainable economic actors locally and globally, and towards present and future generations. Thought-provoking questions on these dimensions were concisely detailed in the briefing material sent to the participants, making sure that they only raise dilemmas but do not frame the thinking process itself.

In a backcasting process, participants jointly create a normative vision for the not-tooclose but still foreseeable future (2050 in our case). Afterwards they define the steps that can lead towards this vision creating a kind of roadmap for interventions [20]. All these took place in a two-day workshop in January 2016 with the participation of the twelve experts. On the first day of the workshop, the participants envisioned what sustainable business in the future would look like. On the second day of the workshop, tools and recommendations were developed along the main focal points of the participants' chosen vision, which could lead to such an ideal future.

As a follow-up to the backcasting workshop, the logical and temporal synthesis of the recommendations was compiled by the researchers together with representatives of the other funding organizations. This also included qualitative tools like meaning condensation, meaning interpretation and categorization based on the researchers' notes and the recordings. To explore the relationships between the vision and the backcasting steps, the researchers prepared tables and charts and drew a systems map [21]. The research report on the backcasting phase was published in 2019 with the results. Some parts of this section rely heavily on this report [22]. 
The backcasting phases were followed by a unique cooperation between art and science $[23,24]$. In 2018, research results were given to an art troupe called Symptoms Ensemble without little explanation on behalf of researchers, and the artists were expected to interpret the results according to their understanding. This was then turned into a theatrical action game and staged three times in three different locations to the public. The purpose of this exercise was threefold. Firstly, it was meant to test how well the cooperation between art and science can lead to enhanced social research results both in terms of understanding and in terms of impact. Secondly, it served as dissemination for the results initiating public discourse. Thirdly, and most relevantly to this paper-the process, the implementation and the dialogues throughout this endeavor-deepened our understanding of the research results and the metaphor of the cuvée organization.

However, after this phase, the researchers felt that they had not capitalized sufficiently on the richness of the metaphor that emerged in the backcasting phases and through the cooperation between art and science. The use of metaphors in futures studies is an extensively applied tool (for more details see Inayatullah [25] in the editorial and the special issue of Futures dedicated to this theme) in order "to make the strange familiar and also the familiar strange" [26]. To further enhance our comprehension of the cuvée metaphor, in January 2020 we organized a workshop together with a scholar specialized in viticulture. The original participants from the backcasting research were also invited, and other faculty members were also welcomed to join.

The research process-resulting in the report on backcasting, the theatrical action game and the mind map on the metaphor-demonstrates that the concept of the cuvée organization is an evolving construct that is developed through stigmergic collaboration [27,28] in participatory processes involving many distinct disciplines.

\section{Meta-Level Conceptualization of the Cuvée Organization}

What would it take to earn a social license to operate a business organization in 2050? To address the question, the expert participants have formulated a vision for 2050 considering wider socioeconomic and narrower organizational aspects. The following is an excerpt from the backcasting vision:

"In 2050, the economy is the subsystem of society, that is the subsystem of the natural environment. They are fully embedded in each other and interact directly and dynamically. The purpose of economic organizations is to serve human communities and nature, and to solve ecological and social Causes (Cause-driven organizations). Profit maximization is not an end in itself. However, profit exists but it is an indicator of value creation in a specific cause. As a result of convergence between the civil and corporate sectors, Cuvée organizations are operating. Economic organizations are organized into ecosystem-like networks. The nodes of the networks are built around core competencies that are needed to address some of the Causes at the heart of economic organizations. The relationship between the organizations is based on coopetition, an expression reflecting open and unrestricted sharing of knowledge and experience. At the same time, a healthy and constructive competition for development exists and is accepted in the economy. There are self-regulating mechanisms in the network that prevent strong power positions from forming. Decisions are made in a decentralized manner within the network and within economic organizations, at the level closest to the point where the given problem occur. The responsibility of economic organizations extends along the entire supply chain, and all those directly and indirectly involved in the supply chain are all considered stakeholders of the economic organization. The economic organization is the arena for democracy both for external and internal stakeholders. The communities concerned can participate meaningfully in the strategic decision-making and planning processes and have the necessary authority to do so. The characteristics of the product make it clear what social and natural impacts occur throughout its life cycle. The operation of the economic organization and the production process of the products are completely transparent. This transparency acts as a self-regulating mechanism in the economy. The 
brand of an economic organization is basically the embodiment of the Cause that it seeks to resolve with its core business."

The single most influential change factor compared to contemporary dominant ways to do business appears to be a meta-level turn: leaving behind profit maximization and instead organizing around cause drivenness. The meta-level is the realm of higher order principles, values and rules which are reflected in the micro-level. The micro-level is shaped by the macro and consists of actions and decisions (relying loosely on Ostrom's Institutional Analysis and Development framework [29]). Abandoning the supremacy of profit maximizing for the sake of serving a prosocial cause has far-reaching consequences regarding multiple fundamental characteristics of a business organization.

Table 2 summarizes the main perspectives that change with the emergence of the cuvée organizations.

Table 2. Meta level comparison of the business approach to be replaced by the cuvée organization.

\begin{tabular}{ccc}
\hline Perspective & Approach to Be Replaced & Cuvée Organization \\
\hline Activity focus & manufacturing/service-provision & solution \\
\hline Motivation & profit-maximization & cause-drivenness \\
\hline Brand & image driven by marketing & the cause \\
\hline Profit & ultimate strategic goal & indicator of success in advancing the cause \\
\hline Systems view & atomistic, self-interested & network-based, embedded \\
\hline Relation to other economic Actors & competition & coopetition \\
\hline Power (market) & globally concentrated & decentralised, relocalised \\
\hline Knowledge & protected by patents & open-source \\
\hline Approach & shareholder view & stakeholder view \\
\hline Relation to staff & employee & partner
\end{tabular}

The central concept behind the cuvée organization is the acceptance that economic organizations are social constructs that operate in an ecosystem that includes strong stakeholders not just in the economic sphere but also in the social and ecological environment. Any activity performed in such intertwined networks has direct natural and social impacts and as such is followed by strong repercussions on the economic actor itself. Hence, the cuvée organization cannot orient its strategies towards self-interested goals such as profit seeking but towards goals that serve the well-being of the whole network (including social and ecological ecosystems). This is where the central theme of the cause itself comes in. In such worldview, the motivational force behind all operations is to choose one specific issue, called the Cause (or multiple issues), that the organization is willing to serve and subordinate all its activities accordingly.

For example, under such circumstances, the goal of a pharmaceutical company is not the research and manufacturing of medication to generate profit but also the provision of health to society with careful consideration to the natural environment. This does not mean that their activities will not include the manufacturing of medication for those whose health has suffered, but it will only be part of their operations that likely to have stronger emphasis on prevention itself. The measure of their success is not how much profit they make by selling more and more drugs but the level of health they provide to humans with the least impact on the natural environment. The focus here is on providing the most effective solutions under the constraints of the ecosystem. If the worst impact on the environment comes from the disposal of excessive dosage of a drug given to an individual through the sewage system, a solution is required to find a way to portion medication according to individual needs. Therefore, the maximum impact needs to be achieved in terms of the cause (serving human health) with the minimum impact on the environment. 
Once the cause replaces the profit logic and the measure of success is the added value to the cause, all those actors that perform tasks related to the same cause become allies in the process. Competition remains because they can still strive to be better at serving the cause, but their success is only reinforced if others are also good at what they are doing. Using our example, other pharmaceutical companies may also serve human health, and the better they are at it, the healthier people are. Other health related actors are also allies, as well as those who can improve the constraints of ecological impact, e.g., purifying sewage water. This is how competition turns into coopetition and the shareholder view extends naturally to a wide stakeholder view. Because the primary purpose is to serve well the common cause, knowledge is widely shared and open-source to enable other nodes in the network to make free use of them. This is also the reason why transparency plays a significant part because it acts as a self-regulating tool within the networks.

Organizational constructs with a cause-beyond or instead of profit as a fundamental goal - have already been conceptualized in academia and operationalized. Figure 1, inspired by Ryder-Vogeley [30] and Wilson and Post [9], captures several constructs along a continuum with social and financial values as primary drivers in mind. It suggests that these values - in our understanding, cause and profit-are at the opposite ends of the continuum and enumerate organizational categories representing various combinations of the two. The cause-social value-is near absent only at one side of the scale; the publicly traded corporations overwhelmingly focus on financial value. All other formats pay attention to social value to a smaller or larger extent. A balanced combination of generating social and financial values is depicted in the midsection of the continuum by social enterprises (SEs) that are often labeled as hybrids. Besides the combined motifs to achieve both social and financial values, social enterprises are often captured as hybrid organizations with characteristics taken from more than one sector. Hybridity might also refer to the organizational format of certain SEs, as well as the double and/or combined target groups of customers and beneficiaries. The latter entails the beneficiaries, i.e., those individuals who are directly linked to the cause of the SE and who derive the main benefits out of social value generation. They might also be the customers of the SE, but beneficiaries are often in other stakeholder roles, i.e., employees. A hybrid format is when, next to a nonprofit foundation, a social enterprise- - a business - is established and provides financial resources from business income to the nonprofit. Figure 1 also illustrates that shifting from the realm of social towards financial value creation, the organizational structure and bylaws allow for a higher degree of personal wealth appropriation. A crucial organizational setup therefore is how organizations-capable of generating financial revenues-can channel surplus resources towards the service of the prosocial cause, instead of transforming them into private income or wealth.

The SE literature has a more varied understanding of the nature of social enterprises, though. Therefore, this straightforward representation of SEs in this continuumdeveloped primarily for impact investors - could be extended to the organizations on its left: smaller ratio or even zero business income and other financial sources that can ensure long-term feasibility instead. There is a wide range of approaches to capture the essence of social enterprises, but when they talk about profit, they are fairly similarly saying that profit alone is not a fundamental goal in itself. Profit is an instrument to achieve social goals. These are "businesses that design their business models based on the alleviation of a particular social or environmental issue. They generate income and attract capital in line with profit-oriented models, nonprofit models, or both" [31] (p. 5). In a broad sense, it involves commercial nonprofits applying business toolkits and business earning strategies as well as social-purpose or mission-based for-profit businesses.

Formats towards the right end of the continuum also contribute to the understanding of the diversity of organizations with an orientation to cause. Both mission-driven forprofits and CSR may vary extensively - even along separate continuums - regarding the cause: its nature, scale, and the embeddedness into organizational strategy, operations and corporate decision making. Besides these key terms, several others can be placed on 
the continuum. There are multiple organizational innovations which aim to safeguard the prosocial efforts against profit pressures. Such are benefit corporations (use state incorporation statutes in the US), B Corporations (certified by a nonprofit), Community Interest Organizations in the UK, Purpose Trusts, Low-Profit Limited Liability Companies, Common Property Prosocial Organizations [32] and Alternative Capitalist [33] to name a few from the Anglo-Saxon legal and institutional field. These organizational innovations can be successful: when averaging environmental worker, governance, community, and consumer scores, B Corps more than double the scores of ordinary benchmark firms [34].

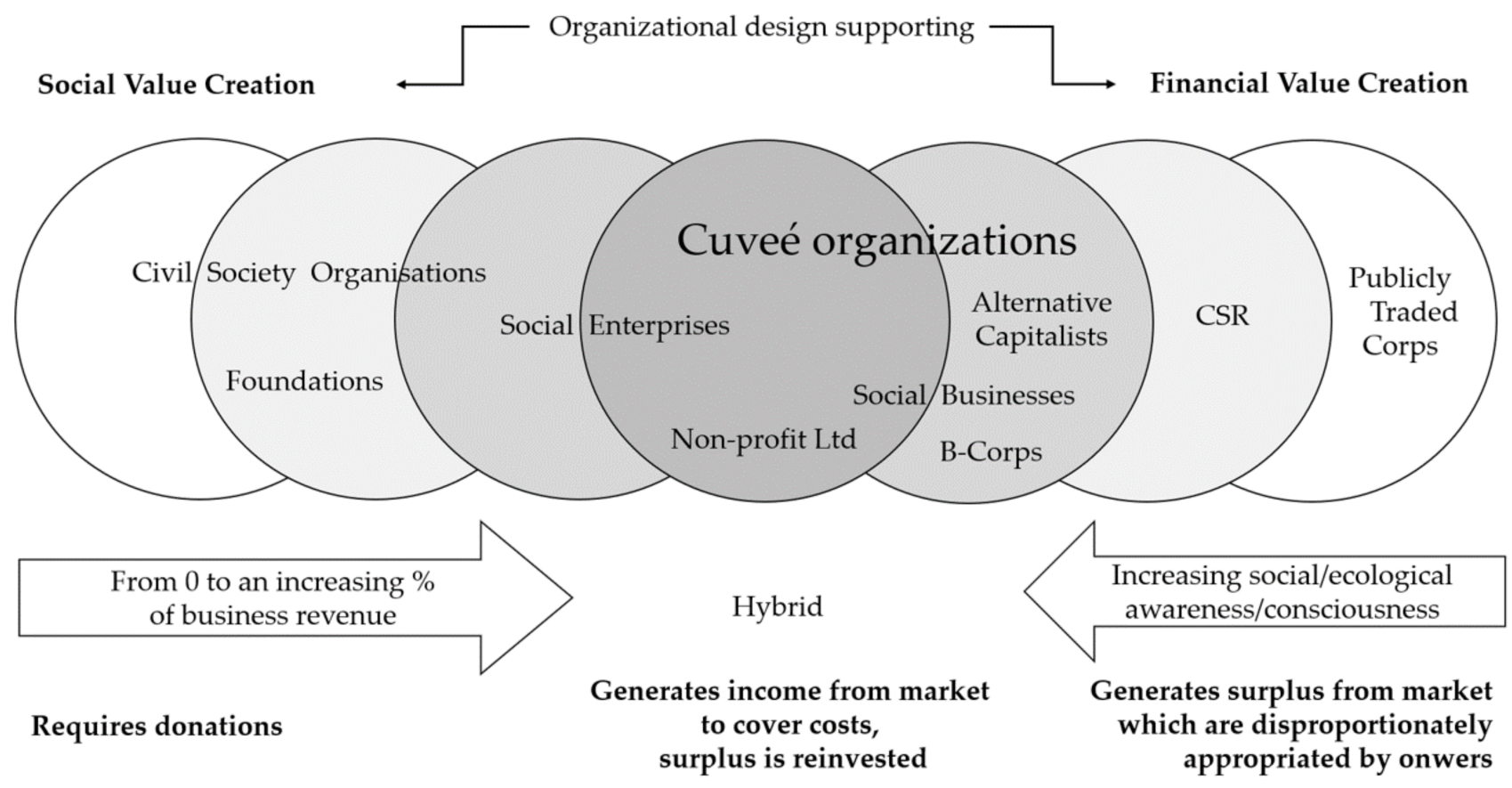

Figure 1. Organizations on the cause-profit coordinate system (inspired by Ryder-Vogeley [30] and Wilson and Post [9]).

When it comes to the vision of the participant experts, the cuvée organization is best described in the literature by the concept of generative ownership design [35]. Generative ownership design has a "living purpose" with a focus on providing livelihoods while creating (or not destroying) the conditions for a dignified life. To do so, argues Kelly [35], top-down absentee ownership has to be replaced by "rooted membership" which is embedded into local social and ecological networks. Price signals and profit expectations as organizing principles have to be succussed by "mission-controlled governance" (called cause-drivenness by the participants) allowing for success to be understood multidimensionally. Finance needs to be subordinated to genuine socioecological needs. These institutional characteristics are reinforcing each other and are meant to serve as checks and balances to safeguard cause drivenness and ethical conduct.

4. Micro-Level Application of the Concept of the Cuvée Organization: The Example of Fighting Discounting for the Sake of Sustainable Decision Making

The complexity of the cuvée organization does not allow us to cover all aspects of its hypothetical operations. Therefore, it is necessary to zoom into a micro-level application where we can focus on one specific perspective of its functioning to test its suitability to sustainability. Hence, we now turn our attention to behavioral economics when introducing the hypothetical organizational form of the cuvée organization as we agree with scholars who say that it is no longer the lack of knowledge that stops us from acting consciously towards our social and ecological environment but certain attributes of human behavior that makes this endeavor difficult [36,37]. Behavioral economics covers a vast field of psychological phenomena like diverse types of heuristics and biases, affect, and emotions. 
For the sake of our argumentation in this paper, to investigate how the cuvée organization might differ from currently known mainstream economic actors in their decision making, it is sufficient for us to focus on one dimension of behavioral economics. Our choice fell on the phenomena of discounting because it poses a serious threat to tackling sustainability challenges and currently constitutes an inherent part of the business environment and acts as a serious barrier to change. After a short introduction to the relationship of discounting and sustainability issues, we will introduce those proposed traits of the cuvée organization that may enable it to counterbalance the innate emergence of discounting in their decisionmaking processes. This should serve as an example of a micro-level application of the concept of cuvée organization.

However, as we venture into the domains of behavioral decision making, it is important to make our stance explicit with regard to the conceptual choices we make in this paper. When it comes to our interpretation of behavioral decision making, our conceptual choice lies with ecological rationality. Ecological rationality supposes that behaviors contradicting the axioms of rationality may still result in successful and accurate decisions. Thus, heuristics and biases-understood as systematic violations of the rational choice theory-should not necessarily have a negative connotation. The rationality of behavior is contextualized; it is contingent on the circumstances of the decision, or as Herbert Simon suggests, on the "structure of task environments" [38] (p. 7). In Simon's pair of scissors analogy, the two blades of cognition - the computational capabilities of the individual—and the context both play a role. The ecologically rational choice is a "match between mind and environment" [39] (p. xix), and this match can be served well with fast and frugal heuristics requiring less time, information, and computation without compromising accuracy.

\subsection{Discounting and Sustainability}

For centuries-mainly since the Enlightenment—economic thoughts revolved around rational choice in decision making. It was only around the 1970s when psychologists like Herbert Simon, Amos Tversky, and Daniel Kahneman managed to hit a hole in this canon. Their work gave rise to behavioral economics, a field that investigates human behavior beyond rationality principles when making decisions in the economic sphere [40,41]. As parallel development, it was also in the 1970s when economists like Herman Daly, Nicholas Georgescu-Roegen, or Kenneth Boulding started questioning another dogma of economic thought, namely the disjunction of the economy from its environment, and they promoted the embeddedness of the economy in the social and the ecological environment. Their work gave rise to ecological economics striving to find a way for the economy to stay within planetary boundaries for the sake of strong sustainability [42]. In current scientific discourses, these two fields often meet up in research that combines the psychological dimensions of behavioral economics and sustainability. This is where limits to rational behavior meet the limits to growth. The topic of discounting in a perfect example.

Although institutionalized discounting in economics and discounting in the psychological realm are strongly related, a distinction must be made. Discounting in economics is an everyday practice justified mainly by marginal opportunity cost of capital and is often criticized by those concerned about sustainability issues because few natural resources can compete with the marginal opportunity cost of capital, and hence profit always reigns over resources [43]. Many argue that the discounting of consumption utility or access to resources is wrong both morally and practically, not only in terms of intergenerational justice but also for aggravating current problems [44,45]. Discounting in behavioral economicssometimes referred to as judgmental discounting-is the phenomenon whereby humans undervalue the risk of an occurrence when it happens in distant dimensions both in time and space [46]. The different dimensions of discounting are uncertainty, temporal, spatial and social distancing with uncertainty closely related to the time dimension and spatial discounting with social distancing. These dimensions influence each other and are similarly influenced by manipulations. While they may not occur simultaneously in all decisionmaking processes, the difficulty with sustainability issues lies exactly with the fact that 
all of them are present at the same time. However, discounting may appear differently when it is seen in terms of losses or in terms of ethical concerns, the latter attracting less discounting [47].

Discounting has a lot to do with psychological distancing both in terms of time and space. Research shows that taking environmental impacts into consideration that happen in the future, 30-40 years from now, are discounted the same way as if they happened outside of one's own country [46]. At the same time, sustainability is a wicked problem that has long-term impacts: we borrow resources from future generations and due to the complex nature of ecological degradation, and the consequences of our decisions may only impact humans and nonhumans geographically distant from us. Hence, costs and responsibilities of an action that follow a decision in the economic sphere to produce or consume may not rest with those who benefit from that production and consumption. However, the emphasis is on perceived psychological distance. Pro-environmental action is less likely to take place when the decision maker perceives that this individual action may only have an influence on people in the distant future or in faraway lands. The reasons behind temporal discounting include the lack of empathy for non-existent fellow human beings, the lack of certainty regarding the future and the inability to delay gratification. Spatial discounting, on the other hand, can be traced back to lesser emotional burdens of seeing a person suffer who is not in our close vicinity, dampening our moral intuition. [46]. Loewenstein et al. [48] argue that when assessing risks while taking decisions, our feelings also deeply impact our judgments. Anticipated outcomes (including anticipated feelings) together with subjective probabilities and other factors such as immediacy or mood have a direct effect on both our feelings and cognitive evaluation that leads to our behavior and final outcomes (including feelings). Therefore, affect has a significant influence on the way we take our decisions. Effects, however, are highly sensitive to proximities in time [48].

The Brundtland Commission's report in 1987 defined sustainable development as "development which meets the needs of the present without compromising the ability of future generations to meet their own needs" [49]. This shows that even the least strict definition of sustainability has the element of assessing impacts in terms of time dimensions ensuring intergenerational equity. Sustainability in this sense is understood as fairness over time towards future generations, and this is why we picked the phenomena of discounting as an illustration in this paper. Environmental concerns and discounting are especially wicked counterparts. Constructive action for the sake of nature is required here, now and for certain considering a potential loss that only just may occur further and later. Our response to this challenge is seriously aggravated by the psychological pressure of only being at ease when focusing on certain things in the present concerning us, or the people we feel close to us [48]. Moreover, judgmental discounting can also neutralize antisocial behavior [36]. While discounting is a phenomenon that seriously hinders sustainability initiatives and constitutes a serious "dragon of inaction" [36], behavioral economics also includes findings on pro-social behavior whereby individuals act based on intrinsic motivation to do good or make sacrifices for others [50], rather than just for the utility of a "warm glow" [51]. In the next subsection, we look at how the cuvée organization was intuitively designed by participants to moderate the impacts of discounting.

\subsection{The Cuvée Organization and Discounting}

Any organization aiming for sustainability has the significant challenge of solving current challenges while maintaining a long-term perspective and aiming for resilience both internally and in their environment. When examining firms with contractual relationship between the top management and the shareholders and comparing them to family-owned businesses, Sanjay and Pramodita Sharma [52] found that ownership is an important aspect of patience in return on investments. Even though both types of organizations' strategic decisions are based on the owners' goals and perspectives, when relational ownership and management apply, these decisions have longer time horizons. When creating value for current stakeholders, it is important to balance them out for values 
of future stakeholders even if these may change in the meantime. However, this often requires long-term investments called patient capital [52]. While patient capital can also be used for malign as well as benign purposes, in our case its sheer existence is crucial in running a cuvée organization whose decision making is supposed to be long-term. Patient capital comes from investors who for various reasons are willing to invest in the long-term, often with the intention to protect certain stakeholders' interests or secure ownership over longer periods of time. The literature on patient capital [53-55] focuses on financial returns on investments in the long-term, the participants in the backcasting research intuitively focused on the role of ownership and investor responsibility. Many backcasting interventions that lead to the rise of a cuvée organization deal with these two perspectives. The resulting systems map shows that participants presumed that a higher level of investor responsibility would decrease the "rate of money-generating function of money" as they called it and hence lead to the strengthening of the cause-driven approaches necessary for the penetration of cuvée organizations in the economic sphere. Urging capital to look for high socioecological return instead of high, short-term financial return on investments was deemed a prerequisite for the rise of cuvée organizations. Even though ownership was discussed as a separate issue, in the patient capital literature the two concepts interrelate. In the backcasting research, employee ownership was seen as a tool to enhance participation in strategic decision making and the representation of diverse stakeholder interests. Through these correlations, however, this proves to be also a tool to fight short-termism and discounting.

Any sustainability transition would require extensive collective action, collective decisions, widespread innovation in terms of organizing our social and economic life and in terms of technology [1]. Even though current mainstream economic thinking tends to build on the self-interest maximizing individual actors, human civilization was made possible through ultrasociality, the capability of a species to cooperate and coordinate even at the expense of individual autonomy [56]. "Humans are not naturally rapacious, hierarchical, and competitive any more than they are cooperative and egalitarian." [56] (p. 16). Ultrasociality has a lot to do with handling temporal and spatial discounting. Ultrasociality itself developed due to the coordinative requirements of human societies that through agriculture managed to produce their own food and create labor divisions that spanned through time and space. The benefit of creating agricultural societies ranged far beyond the lifetime of an individual, but ultrasociality prevailed. While Gowdy and Krall [56] argue that it is exactly this ultrasociality that demands us to unquestionably produce surplus and sacrifice both fellow human beings as well as our own life-supporting systems, it may just be this cooperative nature of ours that can transform the whole system to drive us out of danger. The participants of our backcasting research certainly thought so. Talking about cuvée organizations, the term they specifically used was coopetition. Coopetition-when even competing organizations cooperate to achieve more efficiency-has been said to enhance sustainability but only when the coopetition moves beyond the economic value for the focal firm and produces social good on the macro-level [56]. Manzhynski and Figge [57] (p. 834) argue that "the question whether coopetition for sustainability is viable depends on the perspective of the stakeholders that are involved in coopetition. Different sets of stakeholder interests in coopetition lead to different forms of workable coopetition. Interestingly, this does not necessarily mean that stakeholders need to share the same interests. Our research therefore points to the viability of unusual stakeholder alliances of coopetition for sustainability." This is exactly what participants envisioned both through the cause-driven properties of organizations and through placing cuvée organizations into self-regulating networks where highly diverse sets of stakeholders - even those competing to be the best in advancing the social issue at hand-cooperate extensively. With an interesting crosstalk to our analogy, Christ et al. [58] researched the coopetition arrangements of the two largest wine-producing companies of Australia to cut carbon emissions, and they found the following among the most important factors in the success of coopetition: long-term commitment; the willingness to share knowledge and resources; and building trust [58]. Through such long-term commitments, 
the perspectives for impact also counterbalance our natural tendency to discount the future. Moreover, the wide range of stakeholders-envisioned by the participants-act against social discounting because they are part of the "in-group", the network of the cuvée organization. The vision on sustainable business suggests that stakeholders are to be routinely mapped and heard.

The participant experts described a vision where business organizations are aiming to solve social and ecological issues. An important factor in doing so is the ability of economic actors to share knowledge and experience in an unrestricted way. As Pearce [59] (p. 426) puts it, the "lack of access to critical information for sustainable development is directly responsible for a morally and ethically unacceptable level of human suffering and death." Looking at the US economy, Lindsey and Teles [60] argue that in most sectors, intellectual property rights (the bundle of copyright, patents, and trademarks) have been used as tools by the powerful to gain monopoly, show growth, and increase inequality. In their policy proposal to enhance innovation (and not the rise of intellectual property filings), Boldrin and Levine [61] recommend the phasing out of patents, and until then to tailor their breadth and length to different sectoral needs because there are many alternative options available to reduce the risks and costs of developing new and useful products and services. A solution to this general problem of access to critical information can come through open-source appropriate technology (OSTA). OSTA is a cause-driven approach towards knowledge and technology in that it directs innovation and business models to solve socioecological problems, instead of creating rentier positions. Multiple successful OSTA projects can serve as inspirations and best practices. For example, Kostakis et al. [62] describe how affordable robot hands and prosthetic devices as well as locally manufactured small wind turbines and picohydroelectric plants have been designed and created through open collaborations. Similarly, cheap, customizable, repairable, and durable tools for regenerative farming are being designed, shared and produced through OSTA projects [63]. Open-source knowledge also played a significant role both in the backcasting vision and among the intervention steps that lead to such desirable and sustainable futures.

Stazyk et al. [64] attempt to define the traits of socially responsible organizations who consider social equity as the central focus for sustainability: "socially responsible organizations place a premium on decision making. They engage proactively in strategic planning processes so as to mitigate uncertainty while concomitantly balancing the needs and expectations of present and future generations. More specifically, socially responsible organizations are likely to engage in forms of integrated decision making" (p. 674). They define integrated decision making as a process that ensures that all consequences of an action as well as unexpected potential contingencies are mapped in advance of taking the decision, and those involved in the decision making remain involved not just in the pre-decision phase but also during implementation and evaluation. Organizational structures that best suit such integrated decisions are those where the management hierarchy can easily adapt to changes in missions and is bottomup, inclusive and decentralized. Employee ownership and partial ownership can also be beneficial, and anything that ensures long-term loyalty can enhance such decision-making culture. The organization itself should plan its existence in the long-term, making it easier to resist immediate gains and undervalue future costs. These organizations are more likely also to engage with local communities and embed themselves in the sustainability of their surroundings. The authors also argue that these integrated decisions should stop weighting up interests and focus more on the moral community between generations [64]. This latter argument is in line with the proponents who believe that fighting discounting is to abandon utilitarist approaches altogether because focusing on utilities, enjoyments and interests inhibits moral judgments [44,45].

Our claim is not that a cuvée organization will not use discounting at all. What we argue is that the concept of a cuvée organization provides a space and an organizational structure where discounting is tackled on a more conscious level, following the concept of ecological rationality where heuristics - even temporal discounting - can be treated as part of the individuals' adaptive toolbox [39]. The findings of the backcasting research 
show that even without a specific focus on counterbalancing discounting, participants intuitively based their understanding of the ideal future organization on traits that are supposed to challenge our affinity to discount. These include, for example, decentralized decision making with the involvement of a wide range of stakeholders; extensive use of employee ownership; coopetition and networking; open-source knowledge sharing; and intensive trust building through transparency.

\section{Capitalizing on the Metaphor of Cuvée Winemaking in the Conceptualization of the Cuvée Organization}

Metaphors boost the associative thinking and creative problem solving in a research process $[25,26]$. This was the case in our backcasting research where the invited participants through their cooperative group work had come up with the idea of the cuvée organization by associating the cuvee wine as something that is made up of different grapes (in the analogy containing traits for both current for-profit and nonprofit economic actors) and comparing the development of future business to the process of winemaking. With the emergence of the consensually constructed and elaborated metaphor, the group work became energized; new thoughts and concepts emerged; and an inspired atmosphere was created in which the participants were discovering the deeper and broader layers of their vision of a future company, the cuvée organization. It is out of the scope of this paper to describe the results of understanding the real wine production process of a cuvée wine and translating it to our case of sustainable and responsible future business, but we will use some of the insights we gained in this research process in this section of our paper. We rely strongly on the last phase of our research when a viticulture expert helped us understand the nature of cuvee winemaking. We believe that the use of this metaphor enables us to deepen and elaborate our understanding of an archetypal future organization in sustainable business and express the open questions revolving around the emergence of such organizations.

Cuvée, a word with French origin, means blending, which refers to the fact that the wine is made from the composition of several grape varieties. The essence of cuvée is professional mixing, be it varieties, vintages or even regions. The purpose of the blends is solely to create something even more exciting and complex. The goal is not to upgrade one weaker wine with another because the weaker can never be completely oppressed by a better one, and the good wine is very easily spoiled by the weaker. Not all grape varieties like to be forced into a 'marriage'. Some of them shine on their own, but some also end up in beautiful harmony in the company of another breed. The preparation of cuvée requires serious expertise and confidence because it is necessary to be aware of the characteristics of the married breeds and how they behave together, how they can strengthen or weaken each other. Blending can therefore make the wine more complex in taste, and it can also influence the alcohol content, body and even color. The composition of the blends lies in the hands of the responsible winemaker who is guided by his own inspiration, expertise, openness, patience, and curiosity while also honoring the value in the grapes, the soil, the weather, and the work which made the whole winemaking process possible. Creating a cuvée is more of an art-experimenting with proportions, ingredients, flavors, style features [65]. These subtleties of cuvée winemaking led the participants to use the metaphor when they declared that what they meant by this new organizational type is not merely a hybrid solution marrying current for-profit and nonprofit organizations. Their aim was to introduce a whole new quality to current endowments. Table 3 summarizes the linkages between the cuvée winemaking process and the presupposed and desired development of cuvée organizations in the timespan of the coming decades.

Table 3 indicates that when preparing the necessary intervention steps, the participants used the winemaking metaphor in their thinking. In order to reach cuvée qualities in 2050, in 2020 the world needs to become aware that both current for-profit and current nonprofit forms need to evolve and start learning from each other by sharing knowledge and expertise. This is the only way for all types of "grapes" to improve within their own 
logic. It is only after this sensitizing, awareness-raising and knowledge-sharing phase that the spirit and responsibility of a cause conscious civil sector can be combined with the profit-oriented expertise knowledge of the business sector in the 2030s. The 2040s is all about making this marriage both functional and spiritual in terms of institutionalizing and following alternative mindsets from those inherent to today's economic operations.

Table 3. Cuvée wine making.

\begin{tabular}{ccc}
\hline Backcasting Stages & Winemaking Process & Organizational Developments \\
\hline $\begin{array}{c}\text { 2040s: maturation process with } \\
\text { patience and spiritual awareness }\end{array}$ & $\begin{array}{c}\text { Good quality barrel, sustainable } \\
\text { environment, to gain visibility and } \\
\text { acceptance } \\
\text { (aging, bottling) }\end{array}$ & $\begin{array}{c}\text { Cuvé spirit is embedded and becomes organic } \\
\text { on systemic, organizational and individual } \\
\text { levels. }\end{array}$ \\
\hline $\begin{array}{c}\text { 2030s: choosing the quality wine to } \\
\text { mix — carefully designed and } \\
\text { facilitated process }\end{array}$ & $\begin{array}{c}\text { Good quality wine is needed to create the } \\
\text { desired blend. (fermentation, } \\
\text { clarification) }\end{array}$ & $\begin{array}{c}\text { The spirit and responsibility of a cause } \\
\text { conscious civil sector is combined with the } \\
\text { profit-oriented expertise knowledge of the } \\
\text { business sector. }\end{array}$ \\
$\begin{array}{c}\text { 2020s: preparation of good grape } \\
\text { base for the blending }\end{array}$ & $\begin{array}{c}\text { Careful juice production } \\
\text { (harvest, desteming and sorting, crushing } \\
\text { and pressing) }\end{array}$ & $\begin{array}{c}\text { Mutual awareness raising, sharing of } \\
\text { knowledge, experience, expertise among } \\
\text { economic actors. }\end{array}$ \\
\hline Today's tasks & $\begin{array}{c}\text { Creating a good soil to match the plant } \\
\text { (e.g., hills, near water), finding the region } \\
\text { and valuing the tradition. }\end{array}$ & $\begin{array}{c}\text { Past tradition is understood in order to learn } \\
\text { and overcome them-present focus: } \\
\text { sensitizing. }\end{array}$ \\
\hline
\end{tabular}

The original aim of the participants was to design an ideal organization that represents a completely different quality to the current approaches. The aim of cuvée making is never just to blend different types of grapes but to make the end product better than the wine that could have been consumed without this marriage. Soft wine is married to hard ones not just to balance each other out and result in a compromise but to result in something that is better than just the aggregate of the two distinct grapes. Grape varieties in our case relate to the different organizational forms that exist today, ranging from joint stock companies to nonprofit associations. It comes as no surprise that the participants rejected the use of hybrid as that could have suggested just blending two varieties without significant gains in quality. However, what makes a good wine a good wine can be the subject of vivid discussions without the likelihood of ever finding an answer that satisfies all. Hence, it is the process itself-experimenting with all sorts of marriages in highly different ratios-that matters and the discourse that takes place alongside this process. Moreover, improving the quality of the individual grape varieties also makes sense in this process. Enabling current organizational types to improve their operations within their own logic was deemed as an adequate first step toward, later on, reaching even better cuvée qualities.

The key here is the achievement of "wine harmony" that finds the intricate balance in acidity, alcohol content, color and color defects, intensity, sweetness and sugar content, sulfurization, body, and volatile acids. This is all true in sustainable business organizations. Harmony or balance is to be discovered between individual and collective gains; shortand long-term commitments; the differences in the assessment of the morality behind a cause; costs and benefits; opting in and opting out. In winemaking, all we need is the juice. We do not need the peel, the seeds, the stalk. As an analogy, we could say that in a sustainable world, we could make do without profit, competition, and self-interest maximization. However, as in winemaking, also in our own transition to sustainability, the essence of these also goes into the final product. Certainly, the participants believed so by not rejecting profit but making it an indicator of the success in the cause-not ditching competition but turning it into coopetition and not suggesting that all individual interests must be surrendered to collective needs but by learning how to be assertive without being selfish. However, just as in winemaking, poisonous substances were also discussed in our 
case: bureaucracy, unquestioned beliefs in market mechanisms, absentee ownership, and conscious demand manipulation were to be avoided at all costs.

Experimentation with blending is a vital stage of cuvee winemaking. There is the sensory qualification of wine that suggests that there is an enjoyment value to the end product; it will simply be more enjoyable to live with it. Moreover, smell is an incredibly good indicator of the final result in close analogy of the "smell test" in ethics. There is also the stage of chemical classification-in our business case, trying out different solutions to the same problems. In winemaking, no experimental wines are poured out. In terms of organizations, it is acceptable that some organizations will fail along this path as we must first rely on what we have: artificial scarcity, limited space for innovation. However, blending also supports the maintenance of varieties, and alien grape varieties are also tested when blending. When securing future generations, pluralism can be a key concept. The difference between organic and biodynamic farming is an interesting allegory. Organic viticulture bases itself on being scientific, while biodynamic viticulture brings faith into caring for the process by bringing in methods that rely on old traditions and ancient knowledge. Pluralism in approaches is also crucial in our concepts. While relying on management literature and their own experiences, the participants also brought in concepts on values, traditions, and spirituality into their discourses.

Interestingly, the economic organization of winemaking also provided ample crosstalk during the workshop. Because there are absolute limits in terms of space in winemaking, one can only grow at the cost of power concentration. However, there is a significant difference between winemaking and wine production. The former suggests an artisanal approach where the supply chain is relatively short, and all crucial elements are cared for by the same winemaker. In the latter case, "one produces wine when purchasing too much from others," suggesting an industrial approach. The difference lies mainly between the elements of trust and the supply chain, both topics addressed widely during the research on sustainable business. This is partly the reason why cooperatives are believed to be good and stable organizational forms in the winemaking sector. Interestingly, the notion has come up during our discussions on winemaking that some investors would never drink the wine they invest in, and this is where investor responsibility comes into the picture.

With regards to discounting, one of the insights that came from our viticulture expert could also serve as the motto for this paper. In winemaking, the perspectives of successful operations are much longer than usually granted in other sectors. Any labor, innovation, idea invested today in a vineyard can only be harvested in a minimum of five years, but winemakers normally plan 25 years ahead. This kind of long-term commitment would also be needed when transitioning current organizational forms to bear fruit just in time for us to avert ecological breakdowns.

An additional footnote to the elaborated metaphor on the futures' the company of cuvée organizations is the fact that Hungarians were the members of this research project. The unexpectedly emerged but commonly accepted and cherished metaphor of the winemaking probably has some cultural embeddedness. Hungarians are proudly famous (and even famously proud) for their wines. Béla Hamvas (1897-1968), a great Hungarian writer and philosopher, in his essay on the 'The Philosophy of Wine', discussed three approaches which could give further thoughts and enrich the understanding of our concept on the cuvée organization: first is the spiritual-metaphysical layer; second, the nature bounded, locational layer; third, the nurturing, drinking habits [66] — by giving the complete lifecycle of the wines both in a natural and spiritual sense.

\section{Discussion}

In our discussion, we aim to reflect on the results of both our backcasting research and the conceptualization carried out in the current study. This reflection concerns the importance of our understanding on the meta-level characteristics of organizations, especially those that significantly influence the purpose of business and its social license to operate. Our conceptualization also showed that when testing these meta-characteristics in 
a micro-process of a specific behavioral economics problem, namely discounting, through the common understanding of the most important characteristics of a future organization, participants managed to find adequate solutions to tackle the problem of discounting that is crucial in sustainability transitions, without specifically aiming to address this issue. This draws our attention to the significance of aligning organizational characteristics to facilitate changes in individual choices when it comes to sustainability.

According to Mair and Rathert [67], social inequalities, ecological destruction, unmet local needs, and the disruption of the employment contract's institution are processes which are calling for substantial changes in the way business is currently organized. They argue that the publicly traded corporation is the archetype serving "as the dominant and legitimate form for organizing market-based activity in the 21st century" (ibid., p. 3), and this seems to be substantiated by the fact that 157 of the top 200 biggest economic entities globally (according to their revenues) are corporations outperforming many governments [68]. However, the answers provided by these corporations to sustainability challenges remain unsatisfactory: corporate violence is widespread and takes multiple forms [69-71]. It is therefore of little surprise that Gallup [72] measures a decade's long trend in decreasing levels of trust towards the legitimacy of "business" and that, at the same time, society expects more from business these days than simply creating wealth.

That new types of organizational forms have been called upon in response to such social and ecological disruption is not a new phenomenon. For example, the pressures asserted by the first industrial revolution (as loss of livelihoods and housing due to enclosures, inhumane working conditions, barely or lower than subsistence wages and unsafe working conditions) propelled the foundation of The Rochdale Society of Equitable Pioneers in 1844. Many organizational innovations were introduced, such as the common property regime, the "one person one vote" governance feature, the entitlement for interest due to membership/ownership and other lower-the-burden measures [73] referred to by [74]. These features of the society reflected a prosocial ethos which was deliberately put in practice in response to the specific socioecological context of the time (enclosures, fossil automation, etc.). In our interpretation, the fundamental innovation was partly technical/organizational (for example exact organizational features), but it also had roots in the meta-level, where fundamental values and goals are formed ("an economic organization should not destroy the dignity of workers"). We argue that thinking creatively about organizational forms is more than timely and that attention must be paid to the meta-level. As Schumacher [75] put it, the most important questions regarding the role of market activities "are metaphysical, not scientific." As Zsolnai [76] (p. 1) summarizes, meta-economics concerns three basic assumptions about the subject matter, value orientation and methodology of economics.

Accordingly, Donaldson and Walsh [77] put forward a foundational, meta-level question: "What is the purpose of business?". Their answer does not come from economic, but rather intends to give purpose to human and nonhuman interactions considered to be economic in nature. They offer a normative theory for business. The (i) purpose of business is to optimize well-being on a broad social-ecological level. Business is (ii) accountable to those who are affected by its operations, humans and nonhumans alike; therefore, business control must (iii) prohibit any assault on dignity. Finally, (iv) success is understood through the wellbeing of those affected [77].

The main quest of our research was to find out what organizational features could support such pro-social and pro-environmental meta-level goals and values. Hinton [78], thinking about key dimensions of post-growth business, creates a hierarchical system of organizational characteristics. The more leverage an organizational feature asserts, the higher its position in the hierarchical order. Accordingly, relationship to profit is the single strongest trait affecting an organization because it introduces mechanisms and path dependencies which crowd-out cause-drivenness for the sake of profit generation. The second most powerful trait is the institutional structure (legal form), then comes governance (rules, protocols, and processes by which decisions are made in a business), strategy building and lastly the size and geographical scope of the organization [78]. This 
was certainly substantiated both by the participants' logic of merging organizational traits of nonprofit and for-profit entities into the cuvée organization along the lines of the extent of their cause-driven motivations, and only then does it focus on the governance features of such an organization.

Similar to their central concept of cause-drivenness is "positive social change" proposed by Stephen et al. [79]. They define positive social change as the process of "transforming patterns of thought, behavior, social relationships, institutions, and social structure to generate beneficial outcomes for individuals, communities, organizations, society, and/or the environment beyond the benefits for the instigators of such transformations" (ibid., p. 1252). Organizations focusing on positive social change are characterized as "open" to stakeholder influences, "embedded" in communities, "relational" in that they create social connections, "purposeful" as they are infused with meaning, as well as "strengths based," that is, leveraging existing or building new strengths and capabilities (in targets and within the organization)" (ibid., p. 1268). Stephen et al. [79] concluded that management researchers rarely investigate such organizations; we lack knowledge on their effective management and design. Because the cuvee organization is only mirroring the understanding of the inter-relatedness of these traits in the cognitive processes of experts, it does not provide an empirical insight into how these organizations could work. What it does, however, is draw attention to the key meta-characteristics that determine the behavior of economic actors, and out of those, the relationship to how profit is generated and distributed stands out.

It also appeals to society to focus on these crucial attributes when giving social license to operate. Social license to operate is a concept that promotes the legitimacy of an economic entity by ensuring that its operations are in line with the expectations of the direct and indirect stakeholders as well as the wider society [80,81]. When facing deep-rooted social and ecological concerns mentioned above, this understanding of what attributes are expected from an economic organization in order to gain a social license to operate gain increasing weight. This research and the conceptualization of the cuvée organization advances our understanding of a necessary shift in providing legitimacy to business entities and describes how in an ideal future, these meta-traits would move away from just providing wealth towards framing exactly the social causes they serve. Besides cause drivenness, these traits include the extent of their embeddedness in society and the natural environment; their contribution to the health and well-being of a whole network rather than just their self-interests; the application of coopetition instead of competition; and full awareness of their impacts on stakeholders.

When applying these meta-characteristics to a specific field in behavioral economics, namely discounting, we found that the participants who established the desire to transform economic actors along these meta-characteristics intuitively found adequate solutions to phenomena that hinder sustainability currently. It was not their aim to specifically deal with discounting behaviors; nonetheless, in their discourses they identified the necessity for practices that fight discounting: patient capital, employee or partial ownership, coopetition and networking, open-source knowledge, and transparency. Discounting is a behavioral response that exists in the individual psyche [45] but also in institutionalized forms in organizations and the whole of the economy [42]. Cuvée organizations were not discussed to directly influence individual behavior, but the organization itself provides a space where these automatic cognitive responses can become conscious or can be influenced by organizational practices. While our results show how the characteristics of the cuvée organization can influence institutionalized practices, the relationship between organizational practices and individual pro-environmental behavior is not that straightforward. Organizational requirements towards employees to take environmentally conscious decisions only seem to work if there is some training involved or if they meet the existing value-choices of the individuals [82]. However, pro-environmental behavior is and will be a moral choice after all, and the relationship between the moral character of an organization and the ethical choice and action of an individual has long been established [83]. The Organizational 
Moral Structure suggests that ethical choices in an organization depend on factors such as (1) leader's values and character, (2) vision and exercise of power, (3) corporate control systems, (4) internal network of influence, (5) organizational culture, (6) internal and competitive pressures, and (7) external influences [83]. Therefore, the overall meta-level design of organizations matters in micro-processes of decision making, such as discounting, both in terms of institutional practices and influences on individual behavioral choices.

We appreciate that the variety of organizations already existing in our current economies is even richer than what this paper could portrait. However, discussing the meta-characteristics of the normative concept of the cuvée organization can contribute to the understanding of which traits are crucial in sustainability transitions.

\section{Conclusions}

This paper aimed to inspire the ongoing scientific discourse on the role and responsibility of business organizations in a sustainability transition with a thought-provoking hypothetical concept coming from a backcasting research conducted with an expert panel. By introducing the normative concept of cuvée organization stemming from our qualitative research, we aspired to broaden scientific understanding on how the meta-characteristics of economic organizations such as their motivation, worldview, systems view, relationship to other organizations, society as a whole, their employees and other stakeholders lead to sustainability. Testing this concept to sustainability in general would have been too broad to handle, hence we used one particular perspective of sustainable decision making, namely fighting discounting as a micro-level application of these meta-characteristics. In addition, we believe that the winemaking metaphor is of great help in comprehending the details of the necessary changes in the behavior of economic actors when seeking sustainability.

Cuvée organizations are economic actors that act as strongly embedded nodes in not just economic but also social and ecological networks with a purpose to serve a particular cause important to the whole of that network. This worldview of embeddedness, relatedness, and cause drivenness puts a natural limit to the atomistic, self-centered view of profit maximization and induces coopetition instead of competition when working towards a cause. When applying these meta-characteristics to a specific area, namely fighting discounting in a process of sustainable decision making, our findings show that even without a detailed focus on counterbalancing discounting, participants intuitively based their understanding of the ideal future organization on traits that are supposed to challenge our affinity to discount. These include, for example, decentralized decision making with the involvement of a wide range of stakeholders; extensive use of employee ownership; coopetition and networking; open-source knowledge sharing; and intensive trust building through transparency. Testing the meta-characteristics of the cuvée organization on a micro-level application showed how even in just hypothetical settings, these characteristics matter in everyday decision making that serves sustainability.

We hope that this crosspollination between organizational models, behavioral decision sciences and sustainability literature enriched the theoretical conceptualization and the future visioning of these fields. Our claim is not that a cuvée organization will not use discounting at all. What we argue is that the characteristics of a cuvée organization provide a space and an organizational structure where discounting is tackled on a more conscious level, following the concept of ecological rationality where heuristics-even temporal discounting — can be treated as part of the individuals' adaptive toolbox [38]. On the level of methodologies, our research can contribute to understanding the novelty and applicability of backcasting processes and also provides an astounding example for the use of metaphors in future studies.

All insights provided in this paper are important not just on the theoretical level but could have long-lasting impact on the practice of strategizing and the everyday acts of any organizations aiming to achieve sustainability. We were not aiming to suggest a single feasible solution for the future problems of sustainability but to demonstrate some potential routes to create space for caring, self-reflective, responsible organizational 
practices. By voicing these dilemmas, we are ready to open up new discussions on our role as researchers, business practitioners or policy makers to guide, support or, to a certain extent, lead the sustainability transition in our society. There is no reason why businesses of today cannot start readjusting their practices in terms of the characteristics and practices of cuvée organizations. In fact, there are many economic actors that already follow these normative concepts. For them, it might be encouraging to see that they may be the forerunners of a better future. In future research, the question of what makes those economic entities that resemble the most to the cuvée organizations succeed or fail could be an important one. Normativity can have the trap of overseeing highly practical and pragmatic barriers to change, and therefore, an investigation to these could provide substantial insights.

In terms of the social implications of this research, it is suggested that by reviewing these normative recommendations for a more sustainable future, we can all-both as consumers and as citizens-start re-evaluating the basis on what we provide the social license to operate to economic actors. What might have been acceptable in the past may no longer hold valid in a world where sustainability should become the norm. Backcasting research, with its focus on suggested intervention steps, constitutes, by definition, an action- and policy-oriented tool. While this paper did not include a discourse on the policy relevance of this research, the research report [21] provides ample source of inspiration for policy makers aiming to divert our societies to more sustainable paths. This is also a potential future research direction worth investigating.

We are also aware of certain limitations of our findings and argumentation as the use of the metaphor of winemaking evokes different ideas, processes and associations which may channel our thinking on a pre-defined path. Moreover, our chosen research method of backcasting, a participatory scenario-creating method in itself, may have some limitations if we want to apply the validity-reliability-generalizability framework. The findings are strongly linked to the participants' and researchers' interpretations and value-driven assumptions. We are also aware that these findings only reflect the cognitive understandings and desires of the twelve expert participants, and the socioeconomic background of these participants strongly influences the outcome of this research [84]. It could be highly valuable to run the same processes with more people, or people from diverse backgrounds, or in countries with different dominant social theories. With participatory processes like these, the processes can always be repeated, but outcomes are likely to differ. Nonetheless, they would surely bring more insights to the questions on sustainable business. During the conceptualization phase, we tested the central construct of the participants by applying it to discounting. This choice can also constitute both as a limitation and as a potential future investigation. Applying it to other fields within or outside of behavioral economics could also result in valuable additions to the scientific discourse.

Our further research plans reflect how we highly value such interactive, co-creative, participatory, and mutually inspiring research processes. Through these methods, the personal engagement and active involvement of the actors give a deeper meaning to the commonly constructed concepts. To move beyond the expertise of our backcasting participants and to find a broader audience and continue the discussion on sustainable and responsible business actors both in theory and in practice are among the future plans and aims of our research team. We also hope that some of our readers with different fields of expertise and background find the concept of cuvée organizations inspiring to further develop either in theory or in practice or apply it to existing practices. The backcasting process itself was not funded research. It was the curiosity and commitment of the researchers and the generosity of the participants and cooperating parties that drove this phase of the research. Part of the constraints we faced can actually be overcome by having the chance to involve a much wider pool of experts covering diverse social, geographical, cultural, and professional segments.

It is clear that the originality of the research does not stem from the idea that profitseeking behavior is counterproductive to sustainability. We believe that the novelty comes 
partly from the special participatory research process that relied on backcasting as well as cooperation between art and science and the reliance on the use of an extended metaphor. The current conceptualization of the normative concept of the cuvée organization is also unique. The elaborated use of the metaphor also underpins the originality of the study and brought up relevant issues that can provide new frames of references in our thinking about the sustainability and responsibility of future organizations. Economic actors are and will remain key players in achieving sustainability, and both imagining their desired characteristics and understanding the significance of these characteristics are worthwhile undertakings. In our current conceptualization, they also lead to more sustainable decision making through resisting the urge to discount the future.

Author Contributions: Conceptualization, A.K., J.G., R.M., T.V.; methodology, A.K., J.G., R.M.; formal analysis, A.K., J.G., R.M.; writing—original draft preparation A.K., T.V., J.G., R.M.; writingreview and editing, A.K., T.V., J.G., R.M.; visualization, R.M., T.V.; supervision, A.K. All authors have read and agreed to the published version of the manuscript.

Funding: The corresponding author's contribution was supported by the National Research, Development and Innovation Fund of Hungary, financed under the PD128624 post-doctoral funding scheme.

Institutional Review Board Statement: Not applicable.

Informed Consent Statement: Not applicable.

Data Availability Statement: The results of the backcasting research were published in a research report to be accessed here: http:/ / unipub.lib.uni-corvinus.hu/4463/ (accessed on 7 December 2021).

Acknowledgments: We wish to thank the participants in the backcasting research for devoting their time to the projects and sharing their insights with us. The participants were: Sára Csillag; István Fekete; János Fodor; Ákos Grósz; Gergő Hankó; Áron Jakab; Irén Márta; Katalin Schnierer; Krisztina Schubauer; Anita Simon; Linda Szabó; Judit Varga. We also greatly acknowledge the support of our partner institutions, the Business Council for Sustainable Development in Hungary (BCSDH) and the Civil Auction Foundation (CAF) especially for making the research project possible with their in-kind contributions. We would like to thank in particular István Keresztszeghy, Dóra Kováts, Szilárd Nemes, Irén Márta and Mandy Fertetics for their continued support. We highly appreciate all the insights we gained during our cooperation with the Symptom Ensemble. Especially Péter Valcz who continues to support us in our endeavors to create impact on this issue. Last, but not least we would like to thank Balázs Nagy viticulture expert for educating us with great enthusiasm and commitment what cuvée winemaking is all about. What we know on this topic, we owe to him. We are also grateful to the anonymous reviewers of this manuscript for their valuable comments. Their guidance contributed a lot to the final quality of this paper.

Conflicts of Interest: The authors declare no conflict of interest.

\section{References}

1. Videira, N.; Schneider, F.; Sekulova, F.; Kallis, G. Improving understanding on degrowth pathways: An exploratory study using collaborative causal models. Futures 2014, 55, 58-77. [CrossRef]

2. Nesterova, I. Degrowth business framework: Implications for sustainable development. J. Clean. Prod. 2020, $262,121382$. [CrossRef]

3. Bocken, N.; Boons, F.; Baldassarre, B. Sustainable business model experimentation by understanding ecologies of business models. J. Clean. Prod. 2019, 208, 1498-1512. [CrossRef]

4. Nosratabadi, S.; Mosavi, A.; Shamshirband, S.; Zavadskas, E.K.; Rakotonirainy, A.; Chau, K.W. Sustainable business models: A review. Sustainability 2019, 11, 1663. [CrossRef]

5. Lozano, R. Sustainable business models: Providing a more holistic perspective. Bus. Strategy Environ. 2018, 27, 1159-1166. [CrossRef]

6. Geissdoerfer, M.; Vladimirova, D.; Evans, S. Sustainable business model innovation: A review. J. Clean. Prod. 2018, 198, 401-416. [CrossRef]

7. Bocken, N.M.P.; Geradts, T.H.J. Barriers and drivers to sustainable business model innovation: Organization design and dynamic capabilities. Long Range Plan. 2020, 53, 101950. [CrossRef]

8. da Silva Batista, A.A.; de Francisco, A.C. Organizational sustainability practices: A study of the firms listed by the Corporate Sustainability Index. Sustainability 2018, 10, 226. [CrossRef] 
9. Wilson, F.; Post, J.E. Business models for people, planet (\&profits): Exploring the phenomena of social business, a market-based approach to social value creation. Small Bus. Econ. 2013, 40, 715-737. [CrossRef]

10. Nesterova, I. Small firms as agents of sustainable change. Futures 2021, 127, 102705. [CrossRef]

11. Quist, J.; Vergragt, P. Past and future of backcasting: The shift to stakeholder participation and a proposal for a methodological framework. Futures 2006, 38, 1027-1045. [CrossRef]

12. Robinson, J. Future Subjunctive: Backcasting as Social Learning. Futures 2003, 35, 839-856. [CrossRef]

13. Blaikie, N. Approaches to Social Enquiry; Polity Press: Cambridge, UK, 1993.

14. Hardt, L. Metaphors as Research Tools in Economics. Horizon 2014, 22, 256-264. [CrossRef]

15. Klamer, A.; Leonard, T. So what's an economic metaphor? In Natural Images in Economic Thought; Mirowski, P., Ed.; Cambridge University Press: Cambridge, UK, 1994; pp. 20-52.

16. Golsorkhi, D.; Rouleau, L.; Seidl, D.; Vaara, E. Handbook of Strategy as Practice; Cambridge University Press: Cambridge, UK, 2011.

17. Chia, R. Strategy-as-Practice: Reflections on the Research Agenda. Eur. Manag. Rev. 2004, 1, 29-34. [CrossRef]

18. Jarzabkowski, P. Strategy as Practice, an Activity—Based Approach; Sage Publications: London, UK, 2005.

19. Whittington, R. Strategy after Modernism: Recovering Practice. Eur. Manag. Rev. 2004, 1, 62-68. [CrossRef]

20. Köves, A.; Király, G.; Pataki, G.; Balázs, B. Backcasting for Sustainable Employment: A Hungarian Experience. Sustainability 2013, 5, 2991-3005. [CrossRef]

21. Király, G.; Köves, A.; Pataki, G.; Kiss, G. Assessing the Participatory Potential of Systems Mapping. Syst. Res. Behav. Sci. 2016, 33, 496-514. [CrossRef]

22. Köves, A.; Gáspár, J.; Matolay, R. Research Report on the Results of the Backcasting Workshop on 'What will the Business of the Future look like?'-Sustainable and Responsible Economic Actors in 2050; Corvinus University of Budapest: Budapest, Hungary, 2018.

23. Köves, A.; Gáspár, J.; Matolay, R. Future \& Co.: Bringing the Vision on Sustainable and Responsible Business Closer to People with a Theatre Action Game. Ecología Politica, August 2019.

24. Köves, A.; Gáspár, J.; Matolay, R. The Co-Operation of Art and Social Sciences in the Spirit of Postnormal Science: The Results of a Backcasting Research in an Interactive Theatre Adventure Game. Magy. Tud. 2020, 181, 210-221. [CrossRef]

25. Inayatullah, S.; Izgarjan, A.; Kuusi, O.; Minkkinen, M. Metaphors in futures research. Futures 2016, 84, 109-114. [CrossRef]

26. Gordon, W.J.J. Synectics: The Development of Creative Capacity; Collier-MacMillan: London, UK, 1961.

27. Elliot, M.A. Stigmergic Collaboration: A Theoretical Framework for Mass Collaboration. Ph.D. Thesis, The University of Melbourne, Melbourne, VIC, Australia, 2007.

28. Marsh, L.; Onof, C. Stigmergic Epistemology, Stigmergic Cognition. Cogn. Syst. Res. 2008, 9, 136-149. [CrossRef]

29. Ostrom, E. Institutional Analysis and Development: Elements of the Framework in Historical Perspective. Encyclopedia of Life Support Systems, II; Indiana University: Bloomington, IN, USA, 2010.

30. Ryder, P.; Vogeley, J. Telling the impact investment story through digital media: An Indonesian case study. Commun. Res. Pract. 2018, 4, 375-395. [CrossRef]

31. Haigh, N.; Walker, J.; Bacq, S.; Kickul, J. Hybrid Organizations: Origins, Strategies, Impacts, and Implications. Calif. Manag. Rev. 2015, 57, 5-12. [CrossRef]

32. Peredo, A.; Haugh, H.; McLean, M. Common property: Uncommon forms of prosocial organizing. J. Bus. Ventur. 2018, 33, 591-602. [CrossRef]

33. Pataki, G.Y.; Radácsi, L. Alternatív Kapitalisták. Gazdálkodás az Érintettek Jólétéért (Alternativ Capitalists. Management for the Wellfare of Stakeholders); Új Paradigma: Szentendre, Hungary, 2000.

34. Stranahan, S.; Kelly, M. Mission-Led Employee-Owned Firms: The Best of the Best; Fifty by Fifty: Washington, DC, USA, 2019.

35. Kelly, M. Owning Our Future; Berrett-Koehler Publishers. 2012. Available online: https://community-wealth.org/content/ owning-our-future-emerging-ownership-revolution (accessed on 7 December 2021).

36. Gifford, R. The Dragons of Inaction: Psychological Barriers That Limit Climate Change Mitigation and Adaptation. Am. Psychol. 2011, 66, 290-302. [CrossRef] [PubMed]

37. Fischer, J.; Dyball, R.; Fazey, I.; Gross, C.; Dovers, C.; Ehrlich, P.R.; Brulle, R.J.; Christensen, C.; Borden, R.J. Human Behavior and Sustainability. Front. Ecol. Environ. 2012, 10, 153-160. [CrossRef]

38. Simon, H. Invariants of human behaviour. Annu. Rev. Psychol. 1990, 41, 1-19. [CrossRef]

39. Gigerenzer, G. Heuristics: The foundations of Adaptive Behavior; Hertwig, R., Pachur, T., Eds.; Oxford University Press: New York, NY, USA, 2011.

40. Earl, P. Behavioural Economics; Edward Elgar Publishing: Cheltenham, UK, 1990.

41. Brekke, K.A.; Johansson-Stenman, O. The Behavioural Economics of Climate Change. Oxf. Rev. Econ. Policy 2008, 24, 280-297. [CrossRef]

42. Ropke, I. The Early History of Modern Ecological Economics. Ecol. Econ. 2004, 50, 293-314. [CrossRef]

43. Voinov, A.; Farley, J. Reconciling Sustainability, Systems Theory and Discounting. Ecol. Econ. 2007, 63, 104-113. [CrossRef]

44. Hampicke, U. Climate Change Economics and Discounted Utilitarianism. Ecol. Econ. 2011, 72, 45-52. [CrossRef]

45. Rendall, M. Climate Change and the Threat of Disaster: The Moral Case for Taking out Insurance at Our Grandchildren's Expense. Political Stud. 2011, 59, 884-899. [CrossRef]

46. Sparkman, G.; Lee, N.R.; Macdonald, B.N.J. Discounting Environmental Policy: The Effects of Psychological Distance over Time and Space. J. Environ. Psychol. 2021, 73, 101529. [CrossRef] 
47. Gattig, A.; Hendrickx, L. Judgmental Discounting and Environmental Risk Perception: Dimensional Similarities, Domain Differences, and Implications for Sustainability. J. Soc. Issues 2007, 63, 21-39. [CrossRef]

48. Loewenstein, G.F.; Hsee, C.K.; Weber, E.U.; Welch, N. Risk as Feelings. Psychol. Bull. 2001, 127, 267-286. [CrossRef] [PubMed]

49. World Commission on Environment and Development (WCED). Our Common Future; Oxford University Press: New York, NY, USA, 1987.

50. Pollitt, M.G.; Shaorshadze, I. The Role of Behavioural Economics in Energy and Climate Policy. EPRG Work. Paper 2011, 1130.

51. Andreoni, J. Impure Altruism and Donations to Public Goods: A Theory of Warm-Glow Giving. Econ. J. 1990, 100, 464-477. [CrossRef]

52. Sharma, S.; Sharpa, P. Patient Capital; Cambridge University Press: Cambridge, UK, 2019.

53. Deeg, R.; Hardie, I. What Is Patient Capital and Who Supplies It? Socio-Econ. Rev. 2016, 14, 627-645. [CrossRef]

54. Deeg, R.; Hardie, I.; Maxfield, S. What Is Patient Capital, and Where Does It Exist? Socio-Econ. Rev. 14 2016, 4, 615-625. [CrossRef]

55. Knafo, S.; Dutta, S.J. Patient Capital in the Age of Financialized Managerialism. Socio-Econ. Rev. 14 2016, 4, 771-788. [CrossRef]

56. Gowdy, J.; Krall, L. Disengaging from the Ultrasocial Economy: The Challenge of Directing Evolutionary Change. Behav. Brain Sci. 2016, 39, 1-19. [CrossRef] [PubMed]

57. Manzhynski, S.; Figge, F. Coopetition for Sustainability: Between Organizational Benefit and Societal Good. Bus. Strategy Environ. 2020, 29, 827-837. [CrossRef]

58. Christ, K.L.; Burritt, R.L.; Varsei, M. Coopetition as a Potential Strategy for Corporate Sustainability. Bus. Strategy Environ. 2017, 26, 1029-1040. [CrossRef]

59. Pearce, J.M. The Case for Open Source Appropriate Technology. Environ. 2012 Dev. Sustain. 2012, 14, 425-431. [CrossRef]

60. Lindsey, B.; Teles, S.M. The Captured Economy: How the Powerful Enrich Themselves, Slow Down Growth and Increase Inequality; Oxford University Press: New York, NY, USA, 2017.

61. Boldrin, M.; Levine, D.K. Against Intellectual Monopoly; Cambridge University Press: Cambridge, UK, 2013.

62. Kostakis, V.; Latoufis, K.; Liarokapis, M.; Bauwens, M. The Convergence of Digital Commons with Local Manufacturing from a Degrowth Perspective: Two Illustrative Cases. J. Clean. Prod. 2018, 197, 1684-1693. [CrossRef]

63. Giotitsas, C.; Ramos, J. Report: A New Model of Production for a New Economy. Two Cases of Agricultural Communities; Source Network/New Economics Foundation: London, UK, 2017.

64. Stazyk, E.C.; Moldavanova, A.; Frederickson, H.G. Sustainability, Intergenerational Social Equity, and the Socially Responsible Organization. Adm. Soc. 2016, 48, 655-682. [CrossRef]

65. Vylian. Cuvée Guide. Available online: www.vylyan.hu/egy-ev-a-hegyen/cuvee-kisokos-mit-erdemes-tudni-a-hazasitasokrol/ (accessed on 20 September 2021).

66. Hamvas, B. A Bor Filozófiája. (The Philosophy of Wine), 1945; Medio Kiadó: Budapest, Hungary, 2010.

67. Mair, J.; Rathert, N. Alternative organizing with social purpose: Revisiting institutional analysis of market-based activity. Socio-Econ. Rev. 2019, 00, 1-20. [CrossRef]

68. 69 of the Richest 100 Entities on the Planet Are Corporations, Not Governments, Figures Show. Available online: https: //www.globaljustice.org.uk/news / 69-richest-100-entities-planet-are-corporations-not-governments-figures-show / (accessed on 10 October 2021).

69. Korten, D.C. When Corporations Rule the World, 3rd ed.; Berrett-Koehler Publications, Inc: Oakland, CA, USA, 2015; ISBN 978-1-62656-287-5.

70. Chertkovskaya, E.; Paulsson, A. Countering Corporate Violence: Degrowth, Ecosocialism and Organising beyond the Destructive Forces of Capitalism. Organization 2020, 135050842097534. [CrossRef]

71. Varman, R.; Al-Amoudi, I. Accumulation through Derealization: How Corporate Violence Remains Unchecked. Hum. Relat. 2016, 69, 1909-1935. [CrossRef]

72. Gallup, Confidence in institutions. Available online: http://www.gallup.com/poll/1597/confidence-institutions.aspxi (accessed on 10 October 2021).

73. Fairbairn 2015, B. The Meaning of Rochdale: The Rochdale Pioneers and the Co-operative Principles. In Occasional Papers; Saskatoon, S.K., Ed.; Centre for the Study of Co-Operatives, University of Saskatchewan: Saskatoon, SK, Canada, 1994; Volume 31778.

74. Peredo, A.M.; McLean, M. Decommodification in action: Common property as countermovement. Organization $2019,1-23$. [CrossRef]

75. Schumacher, E.F. Small is Beautiful; Blond and Briggs: London, UK, 1973.

76. Zsolnai, L. Importance of Meta-economics. In Proceedings of the Responsibility in Economics-The Legacy of E.F. Schumacher, Antwerp, Belgium, 22-23 September 2011.

77. Donaldson, T.; Walsh, J.P. Toward a Theory of Business. Res. Organ. Behav. 2015, 35, 181-207. [CrossRef]

78. Hinton, J. Five Key Dimensions of Post-Growth Business: Putting the Pieces Together. Futures 2021, 131, 102761. [CrossRef]

79. Stephan, U.; Patterson, M.; Kelly, C.; Mair, J. Organizations Driving Positive Social Change: A Review and an Integrative Framework of Change Processes. J. Manag. 2016, 42, 1250-1281. [CrossRef]

80. Demuijnck, G.; Fasterling, B. The Social License to Operate. J. Bus. Ethics 2016, 136, 675-685. [CrossRef]

81. Vanclay, F.; Hanna, P. Conceptualizing company response to community protest: Principles to achieve a social license to operate. Land 2019, 8, 101. [CrossRef] 
82. Unsworth, K.L.; Davis, M.C.; Russell, S.V.; Bretter, C. Employee green behaviour: How organizations can help the environment. Curr. Opin. Psychol. 2021, 42, 1-6. [CrossRef] [PubMed]

83. Roszkowska, P.; Mele, D. Organizational Factors in the Individual Ethical Behaviour. The Notion of the "Organizational Moral Structure". Humanist. Manag. J. 2021, 6, 187-209. [CrossRef]

84. Király, G.; Pataki, G.; Köves, A.; Balázs, B. Models of (Future) Society: Bringing Social Theories Back in Backcasting. Futures 2013, 51, 19-30. [CrossRef] 